\title{
ISOTOPE STRATIFICATION IN HIGH MOUNTAIN GLACIERS: EXAMPLES FROM THE PERUVIAN ANDES AND HIMALAYA
}

\author{
By Jerzy Grabczak, Jerzy Niewodniczański, and Kazimierz Różański \\ (Institute of Physics and Nuclear Techniques, Academy of Mining and Metallurgy, \\ 30-059 Kraków, Poland)
}

\begin{abstract}
O}$ and deuterium content was measured in snow and ice samples collected from two crevasses on temperate glaciers high in the Andes and in the Himalaya. The results show that, due to intense exposure to sun, a significant part of the annual accumulation of snow is removed by melting and sublimation, the latter being predominant. There is strong empirical evidence that in natural conditions which are characteristic of both the glaciers studied sublimation of the snow cover can be approximated by the thermodynamic equilibrium process. The short-term fluctuations, though slightly moderated, and longer-term variations can still be observed in the deeper parts of the glaciers in spite of firnification of the snow.
\end{abstract}

RÉsumé. Stratification des isotopes de hautes montagnes glaciaires: exemples tirés des Andes et de l'Himalaya. La teneur en oxygène-18 et en deutérium a été établie à l'aide d'échantillons de neige et de glace recueillis à partir de deux crevasses sur de hauts glaciers tempérés des Andes et de l'Himalaya. Les résultats de cette étude ont prouvé que sous l'effet d'une exposition ensoleillée intense une grande partie de l'accumulation annuelle de neige est enlevée par la fonte et la sublimation avec prédominance de cette dernière. Il éxiste une evidence émpirique forte, que dans les conditions naturelles qui sont characteristiques pour tous les deux glaciers étudies, la sublimation de la couche de neige peut être approximée par un processus d'équilibre thermodynamique. Les fluctuations à court terme quoique légèrement modérées ainsi que les variations à plus long terme peuvent faire encore l'objet d'observation à des profondeurs plus grandes des glaciers en dépit de la firnification de la neige.

ZuSAMmENFASSUNG. Isotopenstratifikation in Hochgebirgsgletschern: Beispiele aus den peruanischen Anden und aus dem Himalaya. Der ${ }^{18} \mathrm{O}$ - und Deuteriumgehalt wurde in Schnee- und Eisproben aus zwei Spalten auf temperierten Gletschern in den Hochanden und im Himalaya gemessen. Die Ergebnisse zeigen, dass wegen der starken Sonneneinstrahlung ein beträchtlicher Teil des jährlichen Schneeauftrags durch Schmelzung und Verdunstung abgetragen wurde, worbei der Einfluss der Verdunstung überwiegt. In Naturverhältnissen, charakteristisch für beide Gletscher, die Sublimation der Schneedecke an dem thermodynamischen Phasengleichgewicht kann approximiert sein. Kurzzeit-Fluktuationen, wenn auch leicht moderiert, und Langzeitvariationen können noch in den tieferen Teilen der Gletscher trotz der Firnifikation des Schnees beobachtet werden.

\section{INTRODUCTION}

Measurements of the heavy stable isotope content of glacier ice can provide valuable information on snow accumulation rates, firnification, and homogenization processes in the upper layers of a glacier and on its water budget. They serve as a tool for dating ice horizons and as an indicator of climate (see Dansgaard and others (1973), Árnason (1976), and Moser and Stichler (1980) for a general review of this problem).

The interpretation of stable-isotope data obtained from temperate glaciers is often complicated by the fact that during the firnification process the short-term (seasonal) variations in the heavy-isotope content of the precipitation are smoothed out considerably and shifted to more positive values by melting and an isotope-exchange process between the snow-firn matrix and the percolating water (Árnason, 1969, 1976). The potential value of temperate glaciers for palaeoclimatological studies depends critically on whether climatically controlled fluctuations in the isotopic composition of precipitation can survive the firnification process. Up to now this 
problem has not been fully clarified. There are only a few examples in the literature of isotope profiles covering a sufficiently long period and of sufficient accuracy to enable useful conclusions to be drawn (Árnason, 1970; Krouse and others, 1977; Schotterer and others, 1977).

This paper presents the results of the analysis of ${ }^{18} \mathrm{O}$ and deuterium in samples collected from two high mountain glaciers, one situated in the Peruvian Andes and the other in the Himalaya. In both cases the samples were taken from a glacier crevasse through approximately the upper $15 \mathrm{~m}$.

\section{SAMPLING SITES}

The Andean crevasse was situated on Broggi glacier in the Huandoy group, Cordillera Blanca, Peru (lat. $9.00^{\circ} \mathrm{S}$., long. $77.58^{\circ} \mathrm{W}$.; altitude $4766 \mathrm{~m}$ a.s.1.). Broggi glacier is typical of a small temperate valley glacier. It can be assumed it is a relict of Yanapaqtsa glacier that has resulted from its post-glacial retreat which is continuing at the present time. The crevasse was located near the equilibrium line in the upper part of the glacier. The measured ice-surface velocity near the crevasse was about $11 \mathrm{~m} \mathrm{year}^{-1}$ (Borowiec and others, 1980).

In the region of Broggi glacier the annual precipitation was estimated at about $1000 \mathrm{~mm}$ water equivalent (virtually all snow precipitation). The maximum snow precipitation occurs in the February-March period. The windy and mostly dry period, corresponding to the months of June-September, is distinctly shown in the profile by dark dust layers arbitrarily asssigned to August.* The sequence of the dust layers indicates that the part of the crevasse examined covers the period from 1961 to 1975 (sampling was done in July 1975). All the horizons in the profile were generally parallel to each other and dipped roughly at $15^{\circ}$ to the south-west with the slope of the glacier surface. Before sampling, about $0.6 \mathrm{~m}$ of the crevasse wall was removed. Two additional water samples were collected, one from the moraine lake and the other from the moraine lake shore, which represented the precipitation during 2 weeks in July 1975. The altitude of the lake was about $4500 \mathrm{~m}$ a.s.l.

The Himalayan crevasse was situated in the upper part of Gannakhui Glacier in Gannakhui Valley, Garhwal Himalaya, India (lat. $30.57^{\circ} \mathrm{N}$., long. $76.92^{\circ}$ E.; altitude $5650 \mathrm{~m}$ a.s.l.). Because of its form, the crevasse which was examined can be regarded as a cornice located in the upper part of the glacier on the northern slopes of the north-west ridge of Dunagiri Peak (7 $066 \mathrm{~m}$ a.s.l.). The crevasse was situated within the accumulation zone of the glacier and dipped at roughly $10^{\circ}$ to the north.

The precipitation in the region of Gannakhui Glacier (annual mean usually exceeds $2000 \mathrm{~mm}$ water equivalent) originates mainly from warm and moist monsoon air masses coming from the south. However, relatively cold autumn-winter precipitation connected with the north-east winds cannot be excluded. In common with observations at the Andean crevasse, the sampled profile also showed distinct dust horizons but these cannot be directly correlated with annual layers. One or two dust horizons are possible each year. Sampling took place in September 1978. Twenty samples were collected from the profile after pre-treatment of the crevasse wall which was the same as that for the Andean sampling.

* The 1969-70 annual layer has two distinct dust horizons. They could be connected with the disastrous earthquake of 31 May 1970. The snowfall was exceptionally high during the preceding winter (see Fig. 1), which could be an additional reason for the great avalanches ("aluvions") in the Cordillera Blanca at the time of the 1970 earthquake, especially the one from the Huascaran Norte slope towards the town of Yungay. 


\section{RESUlts}

The heavy-isotope profiles obtained for each of the crevasses studied are shown in Figures 1 and 2. Data are expressed as $\delta$ values (per mille deviation from Standard Mean Ocean Water (SMOW)). The standard deviation of a single measurement was $\pm 0.15 \%$ o for ${ }^{18} \mathrm{O}$ and $\pm 1.5 \%$ for deuterium. The relation between the $\delta \mathrm{D}$ and $\delta^{18} \mathrm{O}$ values was in each case similar to the socalled World Meteoric Water Line $\left(\delta \mathrm{D}=8 \times \delta^{18} \mathrm{O}+10\right)$ observed in precipitation on a global scale. The best fit of the experimental data gives the following relations: $\delta \mathrm{D}=(7.3 \pm 0.2) \times$ $\delta^{18} \mathrm{O}+(1 \pm 3)$ and $\delta \mathrm{D}=(8.3 \pm 0.1) \times \delta^{18} \mathrm{O}+(18 \pm 2)$ for the Andean and the Himalayan samples, respectively.

The variation of the heavy-isotope content with depth for the Andean crevasse (Fig. 1) reveals several characteristic features. The uppermost annual layer contains the most isotopically

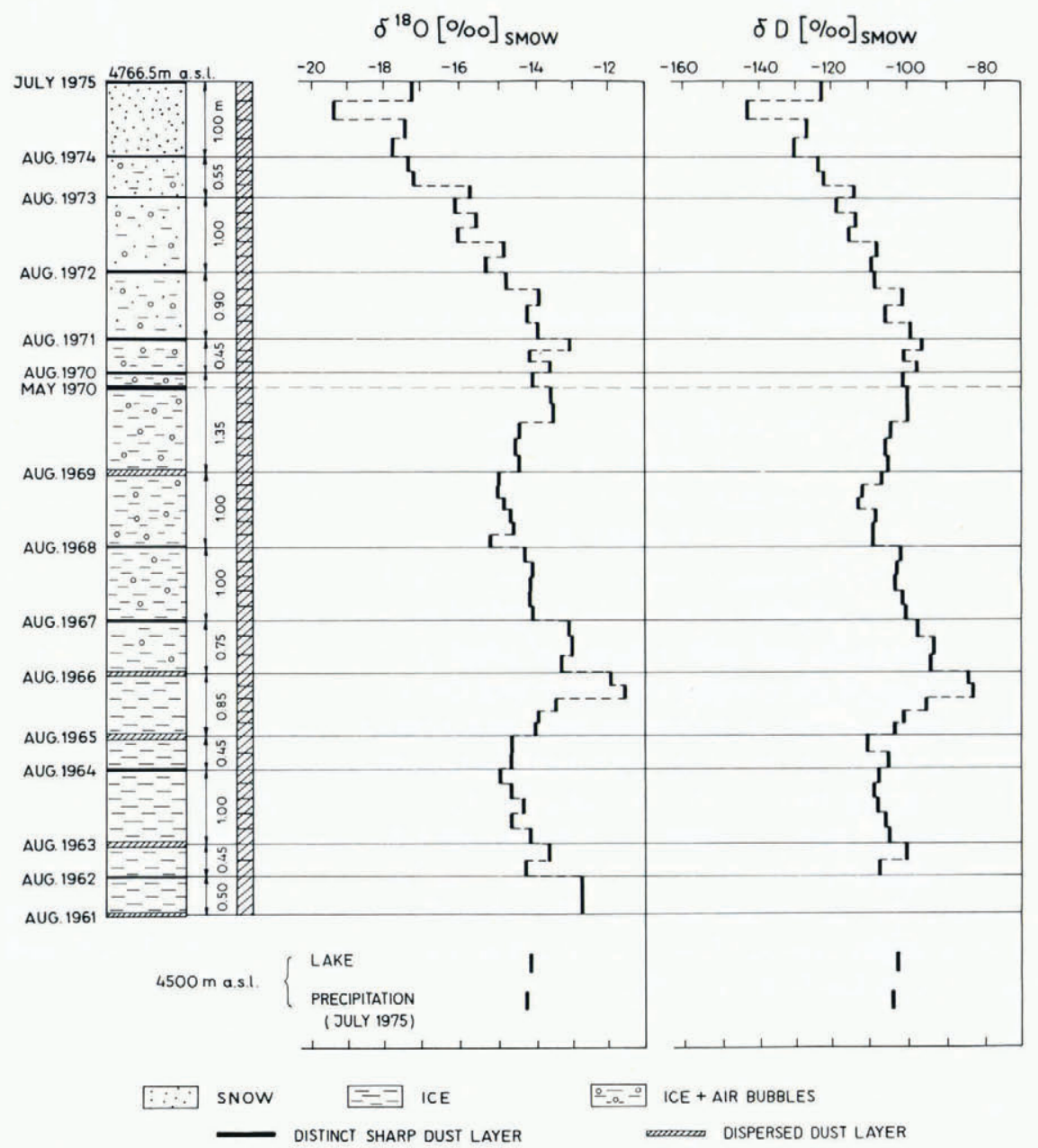

Fig. $1 .{ }^{18} \mathrm{O}$ and deuterium content vs depth for a glacier crevasse situated on Broggi glacier, Peruvian Andes (4 766 m a.s.l.). 


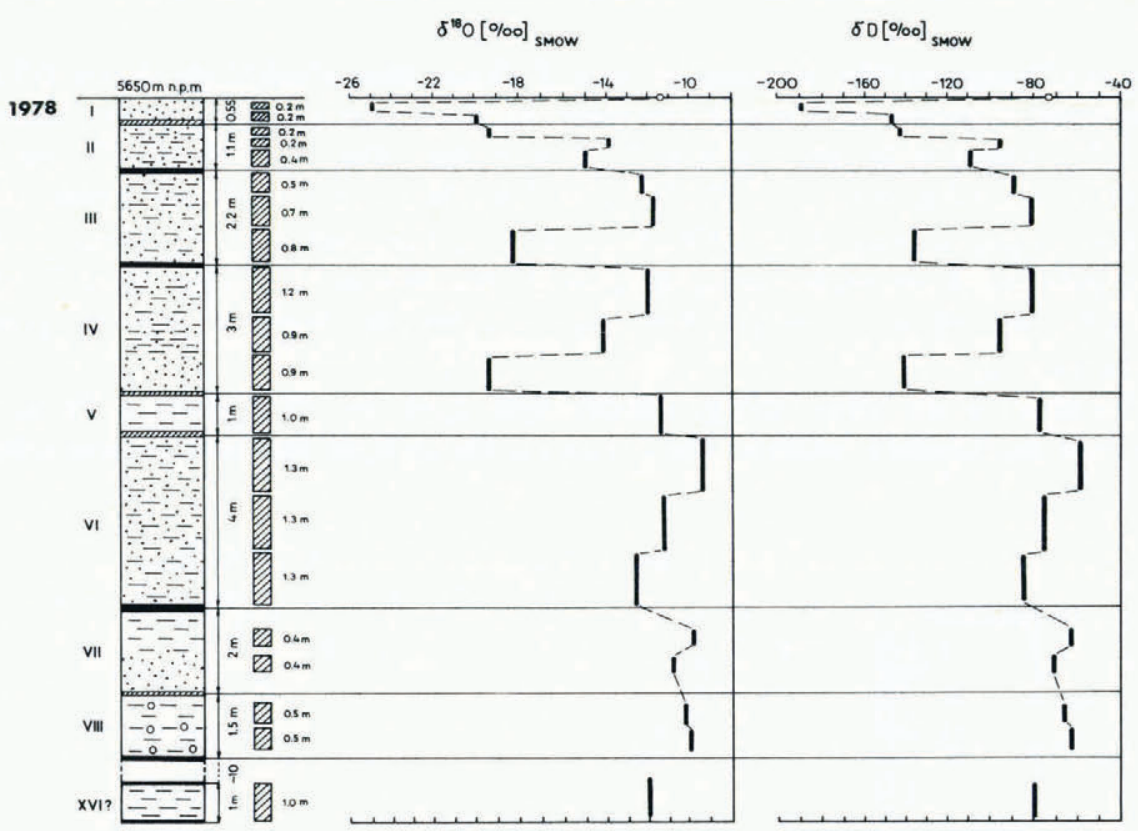

Fig. 2. ${ }^{18} \mathrm{O}$ and deuterium content $v$ s depth for a glacier crevasse situated on Gannakhui Glacier, Garhwal Himalaya, India (5 $650 \mathrm{~m}$ a.s.l.).

depleted samples within the whole profile. The fluctuations of the results are also remarkable. The underlying strata are characterized by a stepwise enrichment of heavy-isotope content, continuing downward to the fifth annual layer. Moreover, the amplitude of isotope fluctuations within particular layers significantly diminishes with depth. A continuous transition from snow to ice can also be observed within this part of the profile. Beneath the 1970-71 layer the heavyisotope content of the sampled ice becomes roughly constant. However, a distinct fluctuation of relatively large amplitude and with a period of about 5 years is quite easy to distinguish. The isotopic composition of the moraine lake water and the precipitation collected on the lake shore lies close to the average value representing the profile beneath the fifth annual layer. The isotopic similarity between these samples is purely accidental (see discussion below).

In the case of the Himalayan crevasse (Fig. 2), the isotope profiles are similar to those measured on Broggi glacier. Despite the much coarser resolution of the sampling, the general trend in heavy-isotope content between the surface and the deeper parts of the profile is the same as that observed for the Andean samples. However, the surface sample reveals a much higher heavy-isotope content compared with the average value observed in the deeper parts of the profile, in contrast to the Andean profile.

\section{Discussion}

Despite the high altitude of each of the glaciers studied, the observed isotope profiles strongly suggest that prevailing conditions are characteristic of temperate glaciers. Distinctive enrichment in the heavy-isotope content compared to the average composition of precipitation over the 
region in question can only be explained if a certain proportion of the annual snow accumulation has been removed from the profile either by melting or sublimation of the snow-cover. The presence of isotopically heavier summer rains, which could eventually interact with the snow-firn matrix and lead to a degree of isotopic enrichment of the solid phase (as is the case in Iceland (see Árnason, 1976)), is practically excluded in each case.

Intense exposure to sun, a characteristic of each of the glaciers studied, should lead to partial melting of the surface snow layers. The water resulting from this process either percolates down to deeper layers of the profile along the slope of the glacier or it can be removed relatively fast from the system through cracks and fissures in the glacier structure. The equilibrium fractionation factor for an ice-water system maintained at $0{ }^{\circ} \mathrm{C}$ is 1.0202 for deuterium and 1.0028 for ${ }^{18} \mathrm{O}$ (from Moser and Stichler, 1980). Thus, melting of snow in equilibrium conditions provides water which is depleted, compared to snow, by about $20 \%$ o in deuterium and $2.8 \%$ in ${ }^{18} \mathrm{O}$. The distinctive depletion in the heavy-isotope content observed in both profiles for the sample collected just below the surface could, therefore, be connected with the presence of melt water from the uppermost layer. It is worthwhile noting that, in the case of the Himalayan profile, the difference between the first and second samples from the top is much greater than might have been expected if isotopic equilibrium within the uppermost part of the first layer is assumed. There are two plausible reasons for this result:

(a) The uppermost Himalayan sample was collected from the surface layer of the glacier snow-cover, whereas the Andean sample represented the first $20 \mathrm{~cm}$ of the profile.

(b) In the case of the Himalayan sample, the snow was aged and distinctly modified when sampled and, therefore, the significant enrichment may be due to sublimation of the snow-cover, in contrast to the Andean sample, which represented fresh snowfall.

Sublimation of the snow-cover is usually considered to be a purely surface process with nonequilibrium kinetic fractionation leading to the $\delta \mathrm{D}$ vs $\delta^{18} \mathrm{O}$ relation with a slope close to 5 , as normally observed for evaporation from open water bodies. Laboratory experiments seem to support such an assumption (Moser and Stichler, [1975]). However, under natural conditions the sublimation process can take place not only at the surface but also within the glacier (strong winds and fluctuations in atmospheric pressure should allow sufficient ventilation within the porous structure of the snow-cover). The isotopic exchange between solid, liquid and vapour phases within the snow-cover should provide conditions for near-equilibrium sublimation processes. Therefore, one should expect the $\delta \mathrm{D}$ vs $\delta^{18} \mathrm{O}$ relation to be similar to that observed for equilibrium processes. The observed slope for this relation is close to 8 for each of the glaciers studied, despite the strong indications of sublimation processes, especially in the case of the Himalayan profile.

A rough estimate of the possible isotopic enrichment that may arise from partial melting of the snow-cover or near-equilibrium sublimation processes can be made by assuming a Rayleightype removal of melt water or water vapour from the system. Table I summarizes a simple calculation based on the Rayleigh equation, ${ }^{*}$ showing the degree of possible enrichment in the course of melting or sublimation of a given snow stratum.

For the Andean profile, the observed difference in heavy-isotope content between the

* The Rayleigh equation, if expressed in $\delta$ notation, is

$$
\delta \mathrm{D}=\delta \mathrm{D}_{0}+\varepsilon \ln F
$$

where $\delta \mathrm{D}_{0}$ and $\delta \mathrm{D}$ are respectively the initial and final deuterium contents in the remaining snow; $\varepsilon=(1 / \alpha)-1$, where $\alpha$ is the equilibrium fractionation factor; $F$ is the fraction of initial mass of snow in the system. 


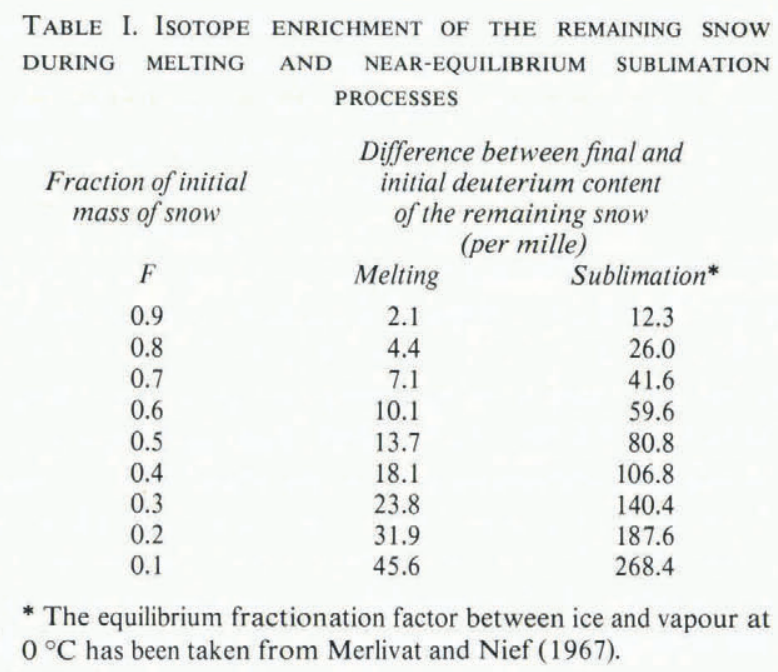

uppermost annual layer and the steady-state value below the transition zone is about $25 \%$ of deuterium. From Table I it is evident that, to obtain such enrichment, more than $70 \%$ of the annual snow accumulation has to be removed when only the melting process is assumed. If the sublimation process alone takes place, then only $20 \%$ of the snow need be removed. In nature probably both processes contribute to the observed enrichment in heavy-isotope content of the glacier snow and ice. However, some influence of medium-term fluctuation of the climate cannot be excluded.

The distinct variations of heavy-isotope content observed in the deeper parts of each profile could be connected either with fluctuations in the isotopic composition of the precipitation or with varying intensity of the melting and sublimation processes. The most probable reason for both effects is fluctuating climate. Especially interesting is a distinct sharp maximum observed in the Andean profile within the 1965-66 stratum. The ratio of the tritium content in these samples to that observed in marine precipitation is 1.8 , whereas the other samples in the profile reveal significantly higher values (2.5-3.8; Niewodniczański and others, 1980). It has been shown by Schell and others (1974) that such a ratio can serve as a useful indicator of the origin of air masses giving rise to precipitation at a given point. The relatively low value of this ratio can be attributed to the prevailing influence of maritime moisture. In this case, the high deuterium and ${ }^{18} \mathrm{O}$ content provides a strong additional argument for such an explanation.

The apparent difference in heavy-isotope content between the uppermost annual layer of the Andean profile and the precipitation collected on the moraine lake shore can be explained by the difference in altitude between these two places (about $260 \mathrm{~m}$ ). This difference, $3.5 \%$ in ${ }^{18} \mathrm{O}$ and $25 \%$ in deuterium, is in general agreement with the values which might be expected for this region (Niewodniczański and others, 1981). The isotope composition of the moraine lake water sample lies close to the mean value of the crevasse samples below the upper transition zone. It can be interpreted that the isotope composition of the lake water is regulated both by the glacier stream and the precipitation. The fact that the isotopic composition falls exactly on the World Meteoric Water Line strongly suggests a rather fast exchange of water in the lake; evaporation apparently does not play a significant role in its water balance. 


\section{CONCLUDING REMARKS}

The isotope profiles discussed here constitute, up to the present time, the only measurements carried out on temperate glaciers situated at such a high altitude. Despite the somewhat tentative nature of the data, they allow us to draw the following conclusions:

(a) Even at a relatively high altitude $(5000-6000 \mathrm{~m}$ a.s.l), glaciers can possess a typical temperate character. Due to intense exposure to the sun, a significant part of the annual accumulation of snow is removed by melting and sublimation processes, the latter being predominant.

(b) In these cases, it seems that the conditions for sublimation of the snow-cover can be approximated to a thermodynamic phase-equilibrium process. Therefore, the isotope fractionation observed in such a process should be very close to equilibrium fractionation. Additional kinetic fractionation normally observed for evaporation from open water bodies seems to be negligible.

(c) Both of the isotope profiles, particularly the Andean one, seem to suggest that the medium-term fluctuations in heavy-isotope content observed in the deeper parts of glaciers may reflect the changes in climate, in spite of strong isotope redistribution occurring during the firnification process. Variation in climate should influence precipitation and secondary processes within the glacier, e.g. ablation, in such a way that the final isotopic composition of the glacier ice is shifted in the same direction. The midlatitude high-mountain glaciers may, therefore, be a source of information on past fluctuations in climate.

Clearly, a great deal of additional experimental data is needed to clarify the above conclusions. Ice samples collected from bore holes situated on selected glaciers should provide the vital data.

\section{ACKNOWLEDGEMENTS}

The authors are grateful to all members of the mountaineering expeditions organized by the Krakow Branch of the Polish Society of Earth Sciences (in particular Dr J. Woźniak) for assistance in collecting the samples. We wish to extend our thanks to J. Rzepka and P. Obrocki for undertaking the isotopic analyses.

MS. received 22 September 1980 and in revised form 11 December 1981

\section{REFERENCES}

Árnason, B. 1969. The exchange of hydrogen isotopes between ice and water in temperate glaciers. Earth and Planetary Science Letters, Vol. 6, No. 6, p. 423-30.

Árnason, B. 1970. Exchange of deuterium between ice and water in glaciological studies in Iceland. (In Isotope hydrology 1970. Proceedings of a symposium on the use of isotopes in hydrology held by the International Atomic Energy Agency in co-operation with United Nations Educational, Scientific and Cultural Organization in Vienna, 9-13 March 1970. Vienna, International Atomic Energy Agency, p. 59-71.)

Árnason, B. 1976. Groundwater systems in Iceland traced by deuterium. Visindafélag İslendinga, 42, p. 60-66.

Borowiec, W., and others. 1980. Broggi glacier and ice sampling site, [by] W. Borowiec, L. Kaszowski, J. Niewodniczański. Prace Mineralogiczne, 64, p. 7-14.

Dansgaard, W., and others. 1973. Stable isotope glaciology, by W. Dansgaard, S. J. Johnsen, H. B. Clausen, and N. Gundestrup. Meddelelser om Grønland, Bd. 197, Nr. 2. 
Krouse, H. R., and others. 1977. Climatic and spatial dependence of the retention of $\mathrm{D} / \mathrm{H}$ and ${ }^{18} \mathrm{O} /{ }^{16} \mathrm{O}$ abundances in snow and ice of North America, [by] H. R. Krouse, R. Hislop, H. M. Brown, K. West, and J. L. Smith. [Union Géodésique et Géophysique Internationale. Association Internationale des Sciences Hydrologiques. Commission des Neiges et Glaces.] Symposium. Isotopes et impuretés dans les neiges et glaces. Actes du colloque de Grenoble, août/septembre 1975, p. 242-47. (IAHS-AISH Publication No. 118.)

Merlivat, L., and Nief, G. 1967. Fractionnement isotopique lors des changements d'état solide-vapeur et liquidevapeur de l'eau à des températures inférieures à $0^{\circ}$ C. Tellus, Vol. 19, No. 1, p. 122-27.

Moser, H., and Stichler, W. [1975]. Deuterium and oxygen-18 contents as an index of the properties of snow covers. [Union Géodésique et Géophysique Internationale. Association Internationale des Sciences Hydrologiques. Commission des Neiges et Glaces.] Symposium. Mecanique de la neige. Actes du colloque de Grindelwald, avril 1974, p. 122-35. (IAHS-AISH Publication No. 114.)

Moser, H., and Stichler, W. 1980. Environmental isotopes in snow and ice. (In Fritz, P., and Fontes, J. C., ed. Handbook of environmental isotope geochemistry. Vol. 1. Amsterdam, New York, Elsevier Scientific Publishing Co., p. 141-78.)

Niewodniczański, J., and others. 1980. Stable isotopes and tritium profile of Broggi glacier, [by] J. Niewodniczaniski, J. Grabczak, L. Baranski. Prace Mineralogiczne, 64, p. 67-73.

Niewodniczański, J., and others. 1981. The altitude effect on the isotopic composition of snow in high mountains, by J. Niewodniczański, J. Grabczak, L. Barański, and J. Rzepka. Journal of Glaciology, Vol. 27, No. 95, p. 99-111.

Schell, W. R., and others. 1974. World distribution of environmental tritium, by W. R. Schell, G. Sauzay, and B. R. Payne. (In Physical behaviour of radioactive contaminants in the atmosphere. Proceedings of a symposium jointly organized by the International Atomic Energy Agency and the World Meteorological Organization and held in Vienna, 12-16 November 1973. Vienna, International Atomic Energy Agency, p. 375-400.)

Schotterer, U., and others. 1977. Isotope measurements on firn and ice cores from Alpine glaciers, [by] U. Schotterer [and 7 others]. [Union Geodesique et Géophysique Internationale. Association Internationale des Sciences Hydrologiques. Commission des Neiges et Glaces.] Symposium. Isotopes et impuretes dans les neiges et glaces. Actes du colloque de Grenoble, août/septembre 1975, p. 232-36. (IAHS-AISH Publication No. 118.) 